\title{
Pemanfaatan media pembelajaran berbasis kelas virtual di masa pandemi
}

\section{Bagas Narendra Parahita1*, Dwi Astutik², Ghufronudin ${ }^{3}$, Yuhastina $^{4}$}

\author{
${ }^{1}$ Universitas Sebelas Maret, Surakarta, Indonesia, email: bagasnarendrap@staff.uns.ac.id \\ 2Universitas Sebelas Maret, Surakarta, Indonesia, email: dwiastutik@staff.uns.ac.id \\ ${ }^{3}$ Universitas Sebelas Maret, Surakarta, Indonesia, email: ghufron.udin@staff.uns.ac.id \\ ${ }^{4}$ Universitas Sebelas Maret, Surakarta, Indonesia, email: yuhastina@gmail.com \\ ${ }^{*}$ Koresponden penulis
}

\section{Info Artikel}

Diajukan: 04 Jul 2021

Diterima: 21 Okt 2021

Diterbitkan: 25 Okt 2021

Keywords:

distance learning; learning media; virtual class

Kata Kunci:

pembelajaran jarak jauh; media pembelajaran; kelas virtual

\section{Lisensi:}

cc-by-sa

\begin{abstract}
During distance learning (PJJ), teachers have difficulty developing creativity regarding the online learning process, especially when compiling learning media. Service activities were carried out by the Eduscape Group Research team from the Sebelas Maret University FKIP together with the Sociology MGMP of Karanganyar Regency as an effort to optimize online learning. The learning media provided by Google for Education, especially Google Slides, was chosen to be the main target for the preparation of virtual classes because it has flexibility, ease of use, and is easily accessible by both teachers and students. The method of implementing service activities is carried out in the meeting room of SMA Negeri Karangpandan, Karanganyar Regency, face to face with stringent health protocols. Service activities consist of material presentation, demonstration, mentoring and collection of virtual class results. The result of this activity is that teachers can compose and use and create learning media through various online platforms (google slides, online quizzes, pdf converters, exploration of material content on youtube) to prepare virtual classes.
\end{abstract}

\section{Abstrak}

Selama pembelajaran jarak jauh (PJJ) guru kesulitan mengembangkan kreatifitas mengenai proses pembelajaran daring terutama saat menyusun media pembelajaran. Kegiatan pengabdian dilakukan oleh tim Riset Grup Eduscape dari FKIP Universitas Sebelas Maret bersama MGMP Sosiologi Kabupaten Karanganyar sebagai upaya untuk mengupayakan optimalisasi pembelajaran daring. Media pembelajaran yang disediakan oleh google for education terutama google slides dipilih menjadi sasaran utama penyusunan kelas virtual karena memiliki fleksibilitas, kemudahan penggunaan, serta mudah diakses oleh pengajar maupun pembelajar. Metode pelaksanaan kegiatan pengabdian dilaksanakan di meeting room SMA Negeri Karangpandan Kabupaten Karanganyar, secara tatap muka dengan protokol Kesehatan yang sangat ketat. Kegiatan pengabdian terdiri dari pemaparan materi, demonstrasi, pendampingan dan pengumpulan hasil kelas virtual. Hasil dari kegiatan ini adalah pengajar dapat menyusun dan menggunaka dan mengkreasikan media pembelajaran melalui berbagai platform online (google slides, kuis online, konverter pdf, eksplorasi konten materi di youtube) untuk kepentingan penyusunan kelas virtual. 


\section{PENDAHULUAN}

Perkembangan modernisasi teknologi informasi dan komunikasi sebagai dampak dari globalisasi IPTEK memberikan pengaruh signifikan bagi progresifnya perkembangan inovasi teknologi dalam bidang pembelajaran. Perkembangan IPTEK yang terjadi menjadi tantangan bagi pengajar untuk terus mengembangkan proses pembelajaran melalui adaptasi teknologi bahkan sebelum situasi pandemi covid-19 terjadi pada awal tahun 2020 di Indonesia. Berbagai teknologi pembelajaran muncul dan berkembang baik mulai dari teknologi berbasis web maupun aplikasi yang dapat dengan mudah diakses masyarakat luas melalui gadget yang mereka miliki. Teknologi informasi dan komunikasi telah memberikan pembelajar maupun pengajar memiliki kesempatan untuk melakukan proses adaptasi pembelajaran dan pengajaran sesuai dengan kebutuhan individu, masyarakat, maupun sekolah (Ratheeswari, 2018). Hal ini sesuai dengan amanah Undang-Undang Dasar 1945 dan Undang-Undang Nomor 20 Tahun 2003 tentang sistem pendidikan nasional yang mengarahkan pendidikan harus menyesuaikan dengan perkembangan zaman serta teknologi. Pembelajaran jarak jauh pada masa pandemi dapat berlangsung karena hadirnya teknologi, utamanya terkait pemanfaatan teknologi internet, namun perubahan proses pembelajaran luring dan daring memberikan tantangan bagi para pengajar (Subekti \& Kurniawati, 2020).

Pada bidang pendidikan proses kemajuan teknologi memberikan kemungkinan berlangsungnya pembelajaran jarak jauh dan berdampak pada peningkatan inovasi yang pesat dalam proses pembelajaran (Almeida \& Simoes, 2019). Kelebihan teknologi pembelajaran yang dapat mengorganisir sistem pembelajaran siswa secara sistematis, efektif dan efisien memudahkan guru untuk membuat sistem pembelajaran menjadi lebih efektif dan tertata. Berbagai contoh website dan aplikasi praktis penyedia layanan teknologi pembelajaran seperti puzzle maker, quizizz, kahoot, videoscribe dan powtoon dapat menjadi referensi bagi para guru untuk menerapkan berbagai teknologi pembelajaran tersebut dalam proses belajar mengajar di kelas yang diampu.

Kendati demikian, berbagai permasalahan terlihat pada riset sebelumnya yang membahas mengenai pemanfaatan Informasi Teknologi Komunikasi atau Information Communication Technology (ICT) untuk peningkatan mutu pembelajaran di masa pandemic Covid-19, hasil riset menunjukkan bahwa untuk menyelesaikan masalah penggunaan media pembelajaran secara daring secara menyeluruh menunjukkan pentingnya sekolah dan guru meningkatkan kemampuan serta pendalaman dalam pemanfaatan teknologi pembelajaran digital yang dapat dimanfaatkan selama pandemi dalam kebijakan dan praktik pendidikan di sekolah (Komalasari, 2020).

Berdasarkan hasil observasi dan wawancara yang dilakukan dengan pengurus dan anggota Musyawarah Guru Mata Pelajaran (MGMP) Sosiologi Kabupaten Karanganyar, dapat diidentifikasi berbagai permasalahan yang dihadapi para guru terkait dengan pemanfaatan media pembelajaran berbasis kelas virtual seperti rendahnya motivasi para guru sosiologi untuk mempelajari teknologi pembelajaran dalam pengembangan kualitas pembelajaran mereka. 
Secara hipotetis, hal ini terkait dengan kebiasaan selama ini yang lebih menekankan pola pengajaran yang bersifat memberi kepada murid, dan murid pasif menerima. Terdapat kesenjangan akses terhadap pengetahuan dan penguasaan informasi berbasis teknologi komunikasi sehingga pemanfaatan melalui inovasi media pembelajaran berbasis informasi teknologi komunikasi tidak mereka lakukan bersama siswa. Kurangnya kegiatan pelatihan, proses pendampingan bagi para guru Sosiologi terkait kegiatan pemanfaatan teknologi pembelajaran berbasis ICT bagi peningkatan kualitas proses pembelajaran dalam konteks merdeka belajar.

Tim riset grup eduscape bermaksud memberikan solusi dengan melaksanakan kegiatan pelatihan bagi para guru dengan pengembangan teknologi pembelajaran berbasis kelas virtual. Pola dalam ruang kelas virtual memiliki fungsi sebagai salah satu platform pembelajaran yang menciptakan ekosistem pembelajaran yang optimal (Charles \& Iwasokun, 2014). Belajar secara online melalui kelas virtual memungkinkan guru untuk mengenal siswa dengan lebih baik (Manegre \& Sabiri, 2020). Model kelas virtual berlangsung efektif ketika disinkronisasi melalui berbagai platform yang mewadahi pembelajaran (Pertiwi \& Sutama, 2020). Model Kelas virtual yang digunakan merupakan kelas berbasis website, tim pengabdian memanfaatkan platform google for education utamanya adalah google slides sebagai basis utama pembuatan kelas virtual. Platform pendukung lain adalah konversi pdf secara online, serta berbagai platform kuis online, di mana guru dan siswa dapat berinteraksi kapan saja, di mana saja tidak terbatas tempat dan waktu. Dengan menggunakan kelas virtual, komunikasi guru dan siswa bisa dilakukan kapan saja dan di mana saja tanpa perlu bertatap muka secara langsung, sepanjang bisa terhubung dengan internet.

\section{METODE PELAKSANAAN}

Kegiatan workshop pengabdian kepada masyarakat dilaksanakan oleh Riset Grup Eduscape dari Program Studi Pendidikan Sosiologi Antropologi, Fakultas Keguruan dan IImu Pendidikan, Universitas Sebelas Maret Surakarta. Kegiatan pengabdian kepada masyarakat dilakukan secara tatap muka di ruang meeting room SMA Negeri Karangpandan Kabupaten Karanganyar pada hari selasa 22 September 2020 dilakukan untuk memenuhi kegiatan tridharma perguruan tinggi. Komunitas guru pengampu mata pelajaran sosiologi yang tergabung dalam kelompok Musyawarah Guru Mata Pelajaran (MGMP) Sosiologi Kabupaten Karanganyar menjadi sasaran kelompok mitra dalam program pengabdian masyarakat kali ini. Guru memiliki motivasi yang tinggi untuk terlibat dalam suatu komunitas kependidikan yang menjadi wadah profesi dengan tujuan meningkatkan keterampilan, mengembangkan wawasan, dan meluaskan jaringan (Kurnia, 2013). Pelibatan guru mata pelajaran sosiologi dalam kegiatan pengabdian ini diharapkan memberikan dampak positif bagi perkembangan media pembelajaran yang digunakan guru dalam proses belajar mengajar. 
Proses pelaksanaan pelatihan pemanfaatan kelas virtual ditunjukkan dalam Gambar 1, tahap pertama kegiatan workshop dimulai dengan pemaparan materi mengenai identifikasi awal tantangan guru dalam menghadapi pembelajaran jarak jauh di masa pandemi sebagai usaha untuk memaksimalkan pembelajaran daring di masa pandemi. Tahapan kedua dilakukan demonstrasi penyusunan kelas virtual dengan memanfaatkan platform Google Slides dengan harapan fitur yang tersedia pada platform tersebut dapat dipelajari dan dikembangkan dengan baik oleh guru berdasar kreatifitas serta pengalaman yang dimiliki para.

Tahapan ketiga dilakukan proses penyusunan kelas virtual dengan pendampingan secara langsung dari tim riset grup eduscape yang melaksanakan kegiatan pengabdian kepada masyarakat. Tujuan pendampingan adalah memfasilitasi guru dalam pembuatan kelas virtual serta membantu kendala yang dihadapi guru dalam proses penyusunan kelas virtual. Tahapan keempat adalah pengumpulan hasil kelas virtual yang telah disusun dikirim ke platform google classroom, kemudian diskusi mengenai potensi platform google slides untuk dijadikan sumber media pembelajaran kelas virtual serta diskusi interaktif ini memfasilitasi para guru untuk saling mengemukakan pendapat mengenai pemanfaatan berbagai media daring pada pembelajaran jarak jauh. Kegiatan empat ditutup dengan evaluasi terhadap hasil yang telah dikirimkan ke platform google classroom untuk menggali potensi kelas virtual yang telah disusun oleh guru.

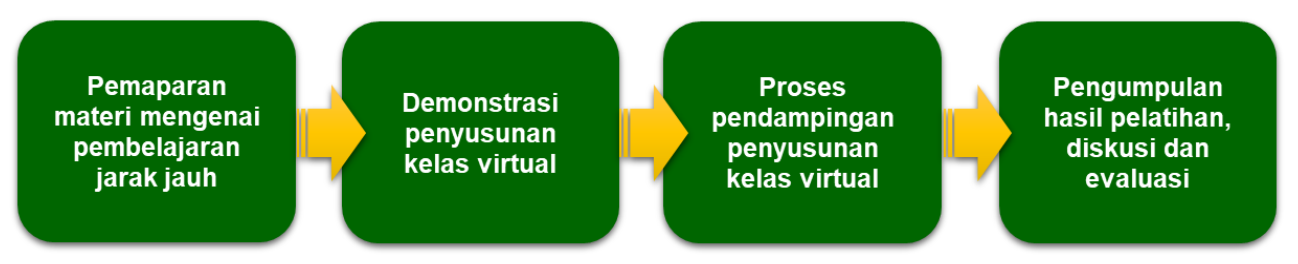

Gambar 1. Metode pelaksanaan

\section{HASIL DAN PEMBAHASAN}

Kegiatan Pengabdian Masyarakat yang berjudul pemanfaatan kelas virtual berbasis kelas virtual pada MGMP Sosiologi Kabupaten Karanganyar dilakukan dengan tujuan mengembangkan kreativitas guru dalam menghadapi pembelajaran daring pada masa pandemi. Kegiatan dilakukan pada MGMP Sosiologi Kabupaten Karanganyar yang dipilih sebagai subjek mitra pengabdian mengingat guru adalah salah satu aktor pendidikan yang berhubungan langsung dengan proses belajar selama Pembelajaran Jarak Jauh (PJJ). Selama masa sulit pandemi berlangsung, hal penting untuk dijadikan perhatian adalah keterlibatan institusi akademis yang dapat mengadopsi pembelajaran daring secara berkelanjutan (Carey, 2020). Diharapkan solusi inovatif dari Riset Grup Eduscape dapat mengatasi berbagai kesulitan guru di masa pandemi. Dengan adanya pelatihan ini diharapkan guru dapat dengan mudah mengimplementasikan kelas virtual dalam proses belajar mengajar di berbagai situasi. 


\section{Proses Pelaksanaan Kegiatan Awal Pengabdian Kepada Masyarakat}

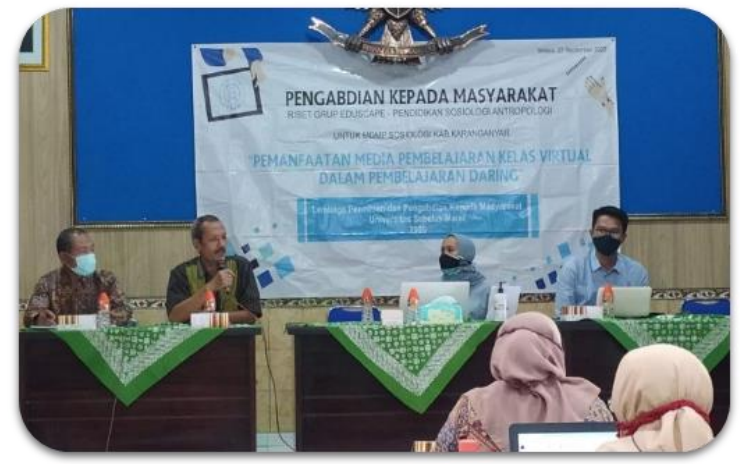

Gambar 2. Sambutan oleh Kepala Sekolah SMA N Karangpandan, Kab. Karanganyar

Kegiatan Pengabdian Kepada Masyarakat (PKM) diberlangsungkan pada hari selasa tanggal 22 September 2020 bertempat di meeting room SMA Negeri Karangpandan. Peserta yang hadir dalam kegiatan ini berjumlah 26 orang dari anggota Musyawarah Guru Mata Pelajaran (MGMP) Sosiologi Kabupaten Karanganyar. Kegiatan awal pengabdian dilakukan dengan memberikan gambaran materi umum mengenai tantangan inovasi media pembelajaran pada saat pandemi berlangsung. Pemaparan materi awal penting untuk mengawali kegiatan pelatihan agar semua aktor pendidikan menyadari bahwa pada kondisi daring ternyata berbagai inovasi pemanfaatan media pembelajaran.

Guru sebagai garda terdepan berlangsungnya proses transfer of knowledge harus mengetahui kebutuhan belajar yang harus dipenuhi untuk peserta didik. Kemudahan penyusunan media pembelajaran, fleksibilitas akses media belajar, serta efektif dan efisiensi penyampaian materi kepada para pembelajar menjadi hal yang penting untuk diperhatikan. Pemanfaatan media pembelajaran yang demikian dapat dilakukan dengan proses identifikasi kebutuhan belajar online selama pandemi. Hal tersebut membuat para aktor pendidikan dapat menyadari bahwa pada situasi serba terbatas saat pandemi telah merubah proses pembelajaran luring ke pembelajaran daring terutama untuk guru terhadap inovasi media pembelajaran daring yang akan digunakan. Pada (gambar 3) berikut ini merupakan salah satu materi yang disampaikan pada kegiatan workshop.
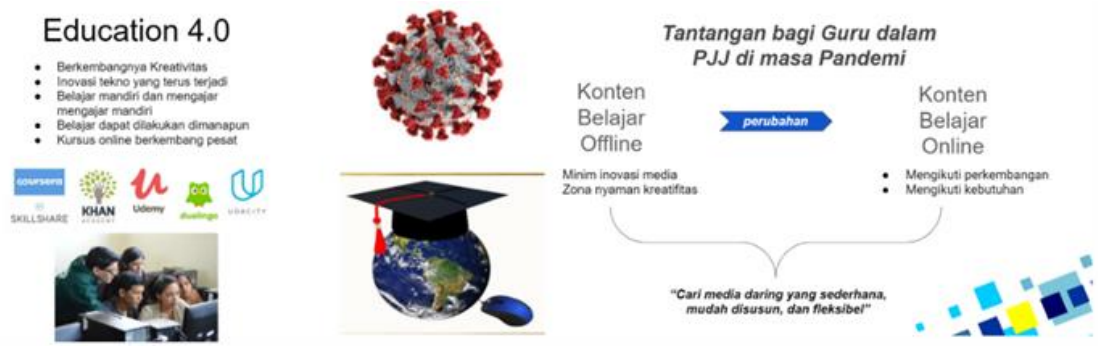

Gambar 3. Materi perihal tantangan Guru saat mengajar daring pada masa pandemi 
Walaupun Pandemi telah terjadi sejak awal tahun 2020 tetapi usaha untuk memberikan materi mengenai tantangan pembelajaran di masa pandemi diharapkan dapat memantik kreativitas para pengajar. Diharapkan ketika pengajar memiliki keinginan untuk mengembangkan media pembelajaran pada pembelajaran daring dapat terjadi optimalisasi proses penyampaian ilmu kepada peserta didik. Usaha guru dapat dilakukan dengan melakukan identifikasi media pembelajaran yang dapat dimanfaatkan secara maksimal dan berkelanjutan.

\section{Demonstrasi Penyusunan Kelas Virtual}

Tim Riset Grup Eduscape menawarkan penggunaan google slides sebagai media yang dapat digunakan sebagai basis penyusunan kelas virtual. Penggunaan berbagai platform Google Slides digunakan sebagai alternatif lain pembelajaran tatap muka yaitu dapat dimanfaatkan untuk pembelajaran daring (Basilaia et al., 2020). Diharapkan media pembelajaran yang disampaikan dapat mudah disusun oleh guru serta mudah diakses oleh siswa.

Oleh karena itu dalam kegiatan ini fasilitator dari Tim Riset Grup Eduscape mencoba untuk melakukan penyampaian informasi berbagai media pembelajaran yang dapat digunakan serta dimanfaatkan untuk demonstrasi terkait proses pemanfaatan platform googles for education yang akan dimanfaatkan sebagai basis penyusunan kelas virtual. Salah satunya adalah dengan melakukan sinkronisasi berbagai media seperti Google Slides, Google Form, pdf converter, kuis online. Beberapa fungsi platform yang akan mendukung penggunaan kelas virtual paling utama adalah platform Google Slide digunakan dan diakses secara online sebagai platform penyimpanan serta membuat tampilan awal kelas virtual. Penggunaan Google Form digunakan untuk membuat presensi kehadiran siswa. Platform Kuis online juga digunakan dan diakses secara online melalui quizizz sebagai platform yang dapat dimanfaatkan untuk evaluasi pembelajaran daring. Berbagai informasi materi tambahan yang dapat diakses pada platform lain seperti youtube disampaikan sebagai bentuk pengembangan konten video materi yang dapat diperoleh oleh pengajar. Penggunaan platform PDF Converter seperti ilovepdf.com dipilih karena dapat diakses secara online agar tampilan awal kelas virtual dapat diakses mudah dalam format pdf.

Beberapa media tersebut dipilih dengan pertimbangan kemudahan pembuatan dan akses kepada peserta didik. Dalam proses penyesuaian materi yang akan digunakan sebagai bahan untuk penyusunan kelas virtual pengajar dapat menggunakan materi Sosiologi sesuai tingkatan kelas yang diampu di sekolah. Adapun gambaran proses sinkronisasi materi terlihat pada (Gambar 4) berikut ini: 


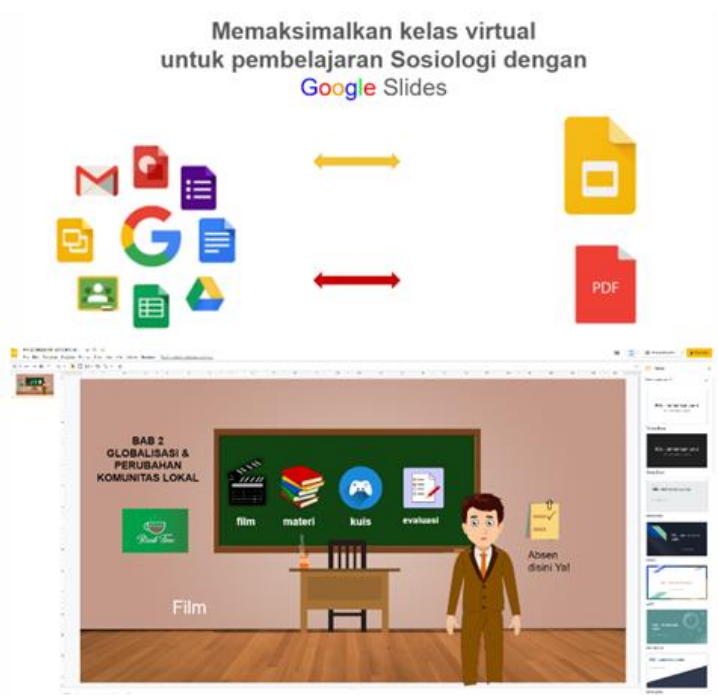

Gambar 4. Materi mengenai pemanfaatan media yang digunakan untuk menyusun kelas virtual

\section{Proses Pendampingan Penyusunan Kelas Virtual}

Setelah dilakukan proses penyampaian materi mengenai media pembelajaran yang akan dimanfaatkan untuk penyusunan kelas virtual, tim fasilitator kemudian mendemonstrasikan proses penyusunan secara langsung diikuti oleh peserta pelatihan. Proses pendampingan agar kendala penyusunan dapat segera teratasi. Pada proses ini terjadilah proses yang interaktif antara fasilitator dengan peserta terkait optimalisasi kelas virtual yang akan disusun sesuai dengan kebutuhan pembelajaran agar dapat memfasilitasi proses belajar mengajar. Dalam kelas virtual yang disusun para guru telah terkoneksi dengan berbagai platform selain google slide untuk isian bahan ajar, evaluasi pembelajaran menggunakan kuis online dan presensi kehadiran menggunakan google form. Berikut situasi simulasi melalui pendampingan penyusunan kelas virtual dapat diamati pada (Gambar 5) berikut ini:

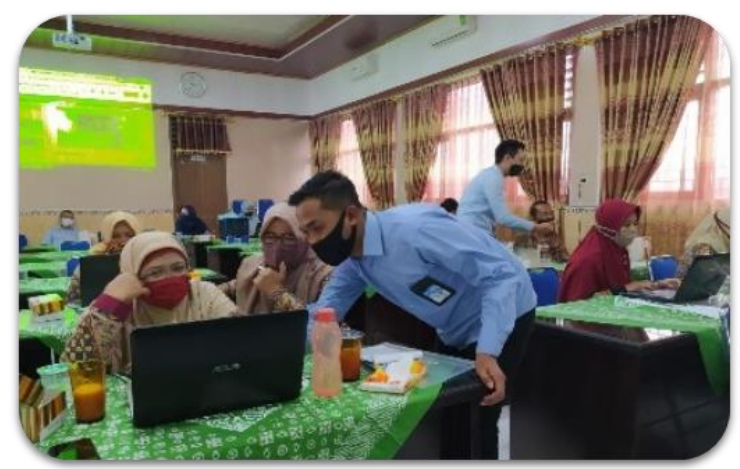

Gambar 5. Tim fasilitator mendemonstrasikan dan melakukan pendampingan penyusunan kelas virtual 
Dalam kegiatan pengabdian kali ini, tim fasilitator mengharapkan kelas virtual yang disusun dapat diimplementasikan pada pembelajaran daring. Pemantauan ruang kelas virtual juga dapat digunakan untuk mengidentifikasi peluang pelatihan, menangani keluhan, dan memverifikasi apakah baik pengajar maupun pembelajar tepat waktu dan mengikuti kelas (Marshall, 2019). Kemahiran memanfaatkan platform Google Slides sangat penting untuk pengajar maupun pembelajar untuk dapat menguasai kegiatan belajar dan mengajar secara online (Ahmad et al., 2020). Dalam kegiatan ini pengajar sangat antusias mengkreasikan kelas virtual yang akan digunakan sebagai salah satu media pembelajaran daring. Setelah peserta menyelesaikan penyusunan kelas virtual pada google slides dan google form, telah ditambah kuis online serta konten video materi dari youtube maka media pembelajaran kelas virtual yang disusun oleh peserta kemudian dikonversi dari google slides menjadi file pdf agar dapat dikirimkan ke google classroom sebagai bahan evaluasi. Identifikasi hasil kelas virtual yang telah disusun pada laman google classroom diperlukan untuk kepentingan pengumpulan hasil karya pelatihan pada kegiatan pengabdian kali ini. Hal itu dilakukan agar para pengajar dapat memaksimalkan segala potensi antar peserta dari hasil kelas virtual yang dikirimkan. Berikut pada (Gambar 6) beberapa contoh contoh produk media pembelajaran kelas virtual yang telah disusun para peserta pelatihan.

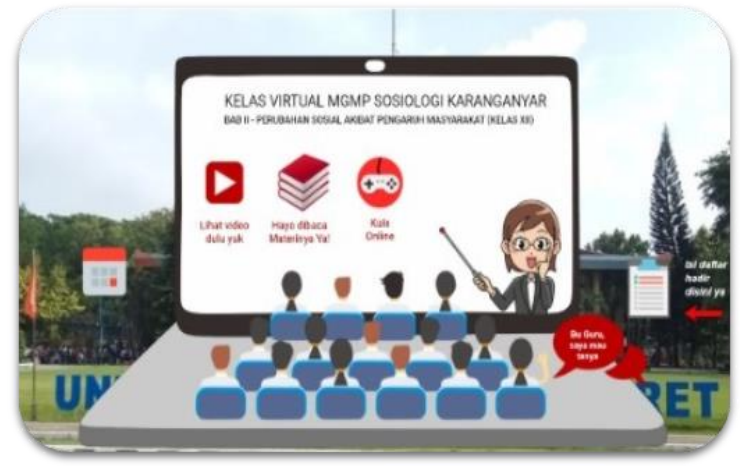

Gambar 6. Contoh hasil kelas virtual yang disusun selama proses demonstrasi oleh fasilitator

Hasil kelas virtual dapat digunakan untuk mengakses berbagai referensi direct link contoh video atau film yang dapat diakses melalui youtube, secara langsung mengarahkan peserta didik untuk mengembangkan content knowledge materi yang telah dipelajari, peserta didik juga dapat mengakses soal dari kuis online, kemudian peserta didik dapat melakukan absensi melalui direct link yang tersedia pada kelas virtual. Adapun beberapa tujuan digunakannya kelas virtual untuk pembelajaran daring dikarenakan kelas virtual mudah disusun, dinamis serta terintegrasi berbagai kebutuhan belajar, penggunaan kelas virtual memberikan keuntungan bagi peserta didik untuk mendapatkan gambaran proses belajar dalam satu akses (film/video, materi, soal, absensi, dll), 
kelas virtual yang tersedia pada google slides maupun file pdf dapat dengan mudah dibagikan kepada siswa melalui berbagai platform (google slides/file pdf dapat dikirim melalui grup whatsapp), penggunaan kelas virtual dapat mendorong siswa untuk dapat meningkatkan keaktifan maupun proses belajar siswa secara mandiri pada masa pandemi serta memberikan kemudahan untuk pengajar untuk melaksanakan pembelajaran secara asinkronus.

\section{Pengumpulan Hasil Kelas Virtual, Diskusi dan Evaluasi Kegiatan Pengabdian}

Proses pengumpulan hasil kelas virtual dilakukan dengan mengirim ke laman google classroom yang telah disediakan agar lebih mudah dalam melakukan kompilasi hasil. Hasil kelas virtual kemudian ditampilkan dalam forum untuk dijadikan bahan diskusi. Total 26 kelas virtual dihasilkan dari kegiatan pengabdian ini, kelas virtual yang dibuat telah menggunakan platform google slides dan telah diinput kuis online maupun konten video sesuai materi sosiologi SMA mulai kelas 10-12 sesuai arahan pada proses demonstrasi hingga pendampingan. Beberapa materi sosiologi yang digunakan pengajar untuk penyusunan kelas virtual adalah materi globalisasi dan dampak pada komunitas lokal, materi kelompok sosial, materi ketimpangan sosial, materi masyarakat multikultural, dan lain-lain.

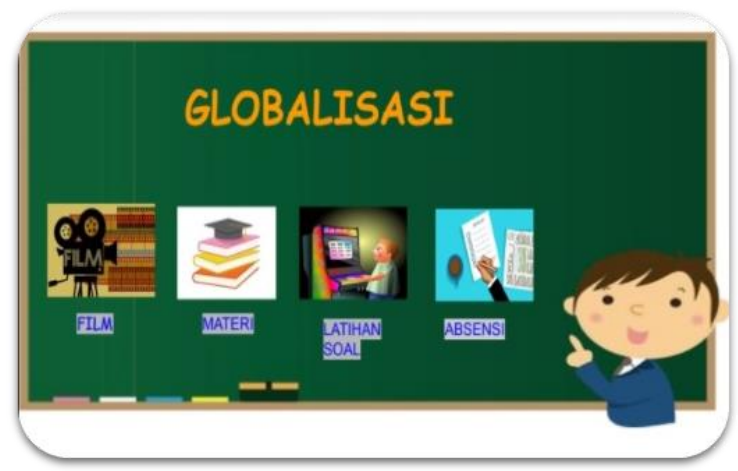

Gambar 7. Hasil kelas virtual yang disusun oleh salah satu peserta kegiatan pengabdian

Setelah proses pengumpulan hasil kelas virtual dipenuhi oleh para peserta pelatihan, kegiatan selanjutnya adalah diskusi dan evaluasi mengenai berbagai hal tentang tantangan dan peluang pembelajaran jarak jauh pada masa pandemi. Pada tahapan diskusi peserta pelatihan saling menyampaikan pengalaman selama pembelajaran jarak jauh juga mengenai pentingnya menguatkan kreatifitas untuk menyusun media yang dibutuhkan para siswa, oleh karena itu memanfaatkan ketertarikan siswa terhadap penggunaan smartphone dengan membuat media pembelajaran yang menarik merupakan hal yang patut dikembangkan karena memang smartphone telah menjadi kebutuhan di masa sekarang ini. 


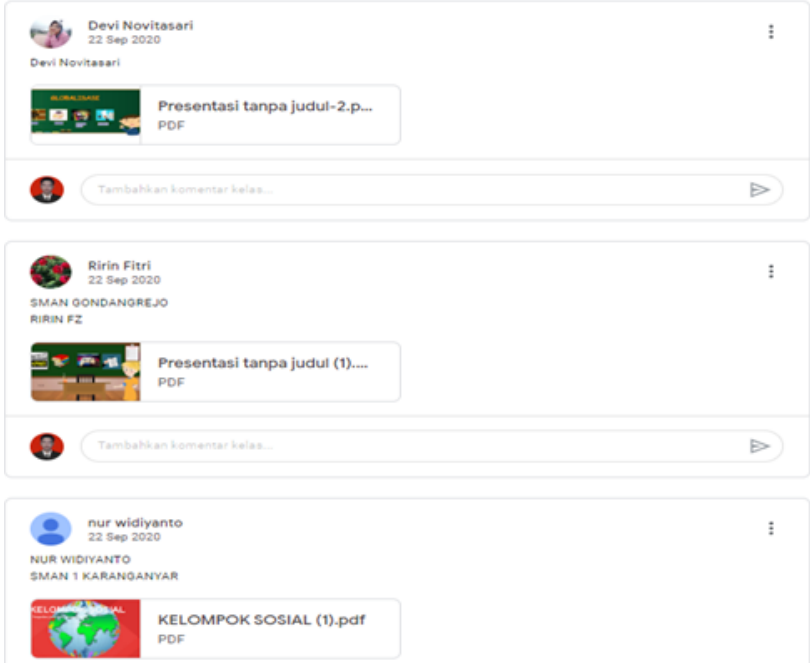

Gambar 8. Hasil penyusunan kelas virtual yang dikumpulkan melalui google classroom

Pada tahapan evaluasi dilaksanakan dengan tujuan untuk mengetahui penguasaan guru terkait berbagai platform yang dimanfaatkan untuk melaksanakan pembelajaran jarak jauh serta pengajar dapat saling melihat hasil kelas virtual yang telah disusun saat workshop dilaksanakan. Data evaluasi yang diberikan adalah bersumber dari respon secara lisan yang diberikan oleh pengajar saat akhir acara workshop dilaksanakan juga melalui kuesioner online terkait ketercapaian kepuasan di akhir acara. Mayoritas pengajar menyampaikan bahwa tertarik untuk memanfaatkan beberapa platform yang telah diberikan selama kegiatan untuk pembelajaran jarak jauh maupun pembelajaran tatap muka kedepannya. Sinkronisasi antar platform (google slides, google form, kuis online, youtube, pdf converter) memberikan kemudahan dalam mempersiapkan media pembelajaran kelas virtual. Simulasi juga dilakukan para pengajar ketika kelas virtual telah terunduh berbentuk pdf dan dapat dibagikan kepada peserta didik melalui whatsapp group atau google classroom.

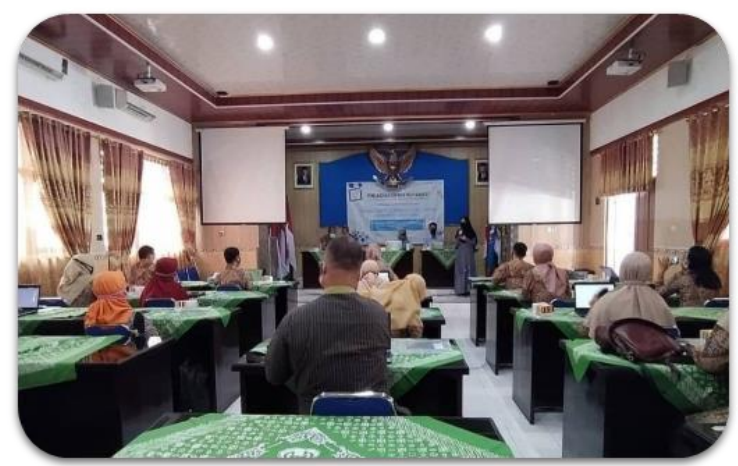

Gambar 9. Situasi diskusi maupun evaluasi kegiatan pengabdian 
Hal lain disampaikan terkait dengan kepuasan para pengajar yang mengikuti jalannya kegiatan terkait dengan materi maupun media pembelajaran selama pelatihan yang dipilih mudah digunakan, diterapkan, maupun dipelajari. Hal lain terkait dengan kepuasan peserta pelatihan disampaikan Ketua MGMP Sosiologi Kabupaten Karanganyar yang menyampaikan pengembangan kerjasama antar akademisi akan memberikan pengaruh positif untuk peserta didik dan para pengajar, hal ini akan sangat membantu peningkatan kualitas pembelajaran Sosiologi di era pandemi dikarenakan ketergantungan terhadap teknologi tidak bisa dihindari. Adapun beberapa hasil ketercapaian kepuasan peserta terhadap kegiatan pengabdian diberikan kepada 26 peserta di akhir acara pengabdian melalui beberapa pertanyaan pada google form menunjukkan bahwa materi yang diberikan ketika kegiatan pengabdian berlangsung dapat dimengerti, proses pendampingan sangat membantu para pengajar dalam menyusun kelas virtual, media pembelajaran yang dipilih dan hasil kelas virtual akan dengan mudah dapat diimplementasikan pada pembelajaran daring. Berikut hasil data prosentase dapat dilihat pada tabel 1 mengenai ketercapaian kepuasan hasil kegiatan pengabdian.

Tabel 1. Hasil ketercapaian kepuasan kegiatan pengabdian

\begin{tabular}{lcccc}
\hline \multicolumn{1}{c}{ Pertanyaan } & $\begin{array}{c}\text { Sangat } \\
\text { Baik }\end{array}$ & Baik & Kurang & $\begin{array}{c}\text { Sangat } \\
\text { Kurang }\end{array}$ \\
\hline $\begin{array}{l}\text { Apakah materi yang disampaikan mudah } \\
\text { dimengerti? }\end{array}$ & $30 \%$ & $62 \%$ & $8 \%$ & $0 \%$ \\
$\begin{array}{l}\text { Apakah pemilihan media pembelajaran yang } \\
\text { digunakan dalam kegiatan mudah digunakan? }\end{array}$ & $34 \%$ & $43 \%$ & $23 \%$ & $0 \%$ \\
$\begin{array}{l}\text { Apakah proses pendamping membantu dalam } \\
\text { penyusunan kelas virtual? }\end{array}$ & $38 \%$ & $62 \%$ & $0 \%$ & $0 \%$ \\
$\begin{array}{l}\text { Apakah hasil kelas virtual sesuai untuk } \\
\text { diimplementasikan pada pembelajaran daring? }\end{array}$ & $38 \%$ & $50 \%$ & $12 \%$ & $0 \%$ \\
\hline
\end{tabular}

\section{KESIMPULAN}

Dari kegiatan pengabdian yang telah dilaksanakan oleh tim riset grup Eduscape dari Fakultas Keguruan dan Ilmu Kependidikan, Universitas Sebelas Maret Bersama MGMP Sosiologi Kabupaten Karanganyar dapat ditarik kesimpulan yaitu, guru harus memperhatikan pola belajar mandiri peserta didik ketika pembelajaran jarak jauh dengan memfasilitasi media pembelajaran yang dinamis, mudah diakses dan menarik. Hal yang dapat guru lakukan untuk mendukung program merdeka belajar selama pembelajaran jarak jauh adalah selalu melakukan pengembangan kreatifitas untuk mempersiapkan bahan ajar untuk peserta didik. Dengan pemberian pelatihan terkait dengan penyusunan kelas virtual, memberikan guru pengalaman baru terkait proses implementasi pembelajaran jarak jauh dengan baik kepada peserta didik di sekolah masingmasing. Sinkronisasi berbagai platform pendukung pembelajaran melalui Google Slides, kuis online, serta eksplorasi konten di Youtube untuk kepentingan pembelajaran dapat dimaksimalkan untuk mengembangkan konten materi yang akan diberikan guru kepada peserta didik. Selain itu, permasalahan guru selama pembelajaran jarak jauh terselesaikan melalui 
diskusi dan evaluasi selama pelatihan berlangsung dengan melihat proses pendampingan penyusunan maupun simulasi hasil kelas virtual yang telah disusun guru serta melihat respon maupun antusiasme dalam mengikuti workshop.

Berdasarkan ketercapaian kegiatan pengabdian harapan besar muncul terkait pengembangan kemahiran pengajar dalam menggunakan teknologi informasi dan komunikasi. Selain itu, para pemangku kepentingan pada bidang pendidikan harus mengakomodasi berbagai kegiatan pelatihan dan pengembangan diri pengajar mengenai penggunaan teknologi maupun media pembelajaran secara berkelanjutan. Salah satunya melalui kerjasama dan kolaborasi antara sekolah dengan pihak eksternal yaitu universitas dengan komunitas guru melalui MGMP harus semakin intens.

\section{UCAPAN TERIMA KASIH}

Tim Riset Grup Eduscape FKIP UNS mengucapkan terima kasih kepada MGMP Sosiologi Kabupaten Karanganyar atas partisipasinya sehingga kegiatan pengabdian kepada masyarakat dapat berlangsung dengan lancar.

\section{DAFTAR RUJUKAN}

Ahmad, M. F., Hassan, W., \& Rohanai, W. A. S. \&. (2020). Learning Using the Google Slides Mobile Application and Its Impact on Attitude, Motivation and Achievement for Industrial Design Subjects in the Tve. Journal of University of Shanghai for Science and Technology , 22(11), 606-613.

Almeida, F., \& Simoes, J. (2019). The role of serious games, gamification and industry 4.0 tools in the education 4.0 paradigm. Contemporary Educational Technology, 10(2), 120-136. https://doi.org/10.30935/cet.554469

Basilaia, G., Dgebuadze, M., Kantaria, M., \& Chokhonelidze, G. (2020). Replacing the Classic Learning Form at Universities as an Immediate Response to the COVID-19 Virus Infection in Georgia. International Journal for Research in Applied Science and Engineering Technology, 8(3), 101-108. https://doi.org/10.22214/ijraset.2020.3021

Carey, K. (2020). Everybody Ready for the Big Migration to Online College? Actually, No. The New YOrk Times. https://www.nytimes.com/2020/03/13/upshot/coronavirus-onlinecollege-classes-unprepared.html

Charles, A. O., \& Iwasokun, G. (2014). Design and Implementation of a WebBased Virtual Classroom System. IOSR Journal of Research \& Method in Education (IOSRJRME), 4(3), 68-77. https://doi.org/10.9790/738804326877

Komalasari, R. (2020). Manfaat Teknologi Informasi dan Komunikasi di Masa Pandemi Covid 19. TEMATIK - Jurnal Teknologi Informasi Komunikasi, 7(1), 38-49. https://doi.org/10.38204/tematik.v7i1.369

Kurnia, I. (2013). Hubungan Supervisi Pembelajaran Dan Motivasi Mengikuti MGMP Dengan Peningkatan Kompetensi Guru. Jurnal Visi IImu Pendidikan, 10(1), 1028-1040. https://doi.org/10.26418/jvip.v10i1.2062 
Manegre, M., \& Sabiri, K. A. (2020). Online language learning using virtual classrooms: an analysis of teacher perceptions. Computer Assisted Language Learning, $\quad O(0), \quad 16$. https://doi.org/10.1080/09588221.2020.1770290

Marshall, F. (2019). Virtual classrooms: a means of digitalizing face-to-face learning and an alternative to e-learning? https://www.global-learningdevelopment.com/2019/04/24/virtual-classrooms-a-means-ofdigitalizing-face-to-face-learning-and-an-alternative-to-e-learning/

Pertiwi, R. K., \& Sutama. (2020). Membudayakan Kelas Digital Untuk Membimbing Siswa dalam Pembelajaran di Tengah Pandemi Covid-19. JKTP: Jurnal Kajian Teknologi Pendidikan, 3(4), 350-365. https://doi.org/10.17977/um038v3i42020p350

Ratheeswari, K. (2018). Information Communication Technology in Education. Conference on "Recent Trend of Teaching Methods in Education" Journal of Applied and Advanced Research, 3, 45-47. https://doi.org/10.21839/jaar.2018.v3S1.169

Subekti, A. S., \& Kurniawati, L. A. (2020). Pelatihan Mendesain Pembelajaran Daring Menarik Selama Pandemi Covid-19 dengan Teknologi Pembelajaran Sederhana. Dinamisia: Jurnal Pengabdian Kepada Masyarakat, $4(4)$, 588-595. https://doi.org/10.31849/dinamisia.v4i4.4679 